\title{
Nutritional vulnerability and associated risk factors estimation of Bangladeshi wetland community people aged 50 years and over
}

Mohammad Meshbahur Rahman ( $\nabla$ meshbahur.rahman@brfbd.org)

Biomedical Research Foundation, Dhaka-1230, Bangladesh https://orcid.org/0000-0001-7471-6042

\section{Zaki Farhana}

Department of Statistics, Bangladesh Bank- The Central Bank of Bangladesh

\section{Md Taj Uddin}

Department of Statistics, Shahjalal University of Science and Technology, Sylhet-3114, Bangladesh

Md. Ziaul Islam

Dept. of Community Medicine, National Institute of Preventive and Social Medicine, Mohakhali, Dhaka1212, Bangladesh.

\section{Mohammad Hamiduzzaman}

College of Health, Medicine \& Wellbeing, University of Newcastle, New South Wales, Australia.

\section{Research Article}

Keywords: Wetland community, older adults, malnutrition, socio-demographic and health factors, Bangladesh

Posted Date: May 26th, 2021

DOI: https://doi.org/10.21203/rs.3.rs-559635/v1

License: (9) (1) This work is licensed under a Creative Commons Attribution 4.0 International License. Read Full License 


\section{Abstract}

People aged 50 years and over often show nutritional vulnerability in South-Asia including Bangladesh. Consequently, they present physical weakness and illness that escalate overtime. In Bangladesh, community-focused investigations have potentials to inform healthcare interventions, but current studies examine older adults' nutrition status which are not all-encompassing [e.g., wetland communities]. We, therefore, assessed the malnutrition status among wetland community-dwelling older adults aged $\geq 50$ years in Bangladesh. A cross-sectional survey with 400 older adults was conducted in the north-eastern wetland community of Bangladesh through simple random sampling. Demographic and health information were collected using a structure questionnaire and the Nestle Mini Nutrition AssessmentShort Form criteria was used to assess the nutrition status. Respondent's socio-demographic and health profiles were assessed, and the Pearson's Chi-square association test was performed to identify the associated socio-demographic and health factors of older adult's malnutrition. The prevalence of malnutrition and risk of malnutrition were 59.75 and 39.75 percent respectively. Malnutrition prevalence rate was higher with increasing of age and female were more malnourished than male. The age, gender, educational status, occupation and income were significantly associated with older adults' malnutrition. The wetland community-dwelling people who are suffering sleeping disorders and poor self-rating health condition were found to be more malnourished. The findings confirm that the prevalence of malnutrition and risk of malnutrition are high among community-dwelling people aged $\geq 50$ years in wetland communities. Our findings suggest the health professionals to implement public health and clinical interventions simultaneously to improve nutritional status of this cohort.

\section{Introduction}

The Goal-2 of Sustainable Development Goals (SDGs), 'Zero Hunger', sets the member states of United Nations on a path of achieving food security and eradicate malnutrition for their citizens by 2030 [1]. Malnutrition refers to the deficiencies, excesses, or imbalances in an individual's consumption of nutrientdense diets [2]. According to World Health Organization (2020), one-third of low- and lower-middle income countries currently experiences extreme malnutrition, particularly in Africa, the Pacific, and the South and East Asia. Many people are being exposed to under-nutrition because of food shortage and obesity due to changing eating habits. As such, about 30 percent people of all ages are undernourished and 20 percent are overweight in low- and lower-middle income countries [3]. To eliminate malnutrition in these countries, there is an importance to understand: who are the malnourished; where they are located; and why they are malnourished.

The people aged 50 years and over are generally inclined to malnutrition because of their physiological, psychological and functional changes that occur with aging [4]. As noted earlier, this prevalence is high in low- and lower-middle income countries that results in negative health effects at old age, such as reduced immunity, physical and intellectual disability, and compromised productivity [5]. According to 
Spencer et al. (2012) and Vafaei et al. (2013), the physical and psychological health problems including anemia, poor memory, weak immune system, infections, muscle weakness, tiredness, unintentional weight loss, depression and anxiety are closely related to malnutrition and common in older adults [6,7]. Malnutrition also increases their risk of comorbid and chronic conditions, for instance, overweight and obesity are major causes of type-II diabetes, respiratory and cardiovascular diseases, various cancers and multiple organ failure [8]. Such morbidity and comorbidity patterns among the adults inform a stipulation of community-based investigation of malnutrition risks in low- and lower-middle income countries including Bangladesh.

Our paper focuses on Bangladeshi wetland community-dwelling older adults' [ $\geq 50$ years - referred as older adults in this paper] malnutrition risks and their associated factors. Bangladesh, a lower-middle income country, has been identified as having one of the largest river deltas in the world. Total area of the country's wetlands [generally referred as rivers and streams, freshwater lakes, marshes, haors, baors, and beels] is estimated to be eight million hectares [9]. The major wetlands of the country include Hakaluki haor, Chalan beel, Atrai basin, Punarbhaba floodplain, Gopalganj-Khulna Beels, Arial Beel, and SurmaKushiyara floodplain [10]. The country has been experiencing a rapid growth in the number of people aged 50 years and over and the proportion of these people is 16 percent of the country's total population [11]. About 73 percent of the adults live in rural areas and of them, 30 percent live in wetland villages [12]. Literature reports that women of reproductive age and children live in wetland villages are susceptible to malnutrition because of natural hazards, health illiteracy and food insecurity, while nutrition-related data for the people aged 50 years and over is not well-documented [11,12]. Therefore, we aim to: (a) review the literature to contextualize ageing trends, nutritional aspects and wetland communities in Bangladesh; and (b) conduct a cross-sectional research to determine the prevalence of malnutrition, malnutrition risks and the factors associated with malnutrition of wetland aging.

\section{Literature Review: Ageing, nutritional aspects, and wetland communities in Bangladesh}

Bangladesh has the third largest population of poor older adults in the world [13]. Older adults accounted for five percent of the total population of Bangladesh in 1991 and nine percent in 2015, and it has been projected that one in every five persons will be classified as elderly in $2050[14,15]$. It is also expected that this proportion of older adults will be equal to the proportion of young people in the second quarter of the $21^{\text {st }}$ century [13]. This ageing pattern has become a major challenge in Bangladesh due to a steady increase in the size of the older population with poor living conditions and scarce resources, especially in the wetland communities.

Malnutrition rate is the highest in Bangladesh among the world and almost one-third were suffering from malnutrition. Many people in Bangladesh eat less or eat energy-dense food of low nutrition value as they get older and they are at risk of malnutrition and related health problems. The primary malnutrition of the 
older adults is caused by a lack of energy (fats and carbohydrates), protein and micronutrients (vitamins and minerals) in the diets of infants and children and the secondary malnutrition is caused by the lack of one or more nutrients in adult diets, ranging from energy deficiency in anorexics to vitamin deficiencies in older people with poor appetite [16]. This risk is high among the older adults, especially in the country's wetland communities, because they are deprived of basic humanitarian needs and live under extreme poverty.

About one-third of the Bangladeshi older adults live in wetland villages. Evidence shows that wetlands provide many benefits for people, for example, fisheries and agriculture are the two major livelihoods for the wetland people and there is an access to high nutrient and fiber foods [17-19]. But these villages are perceived as the place of undernourished or malnourished because the food consumption process remains unhealthy due to a lack of health consciousness [20]. The general education rate is low and heath illiteracy is high in the wetland villages and this factor together with an inadequate nutritional programs and services may impact significantly on their malnutrition [20-23]. According to literature, the older adults in wetland communities are vulnerable than main land population and other wetland community groups to malnutrition for many reasons including hunger and low food intake, physiopsychosocial and functional changes that occur with age, and inadequate access to food [24,25]. Their problem is compounded by poor nutrition together with physical illness, including both communicable and non-communicable diseases.

In Bangladesh, the ageing and nutrition aspects in wetland communities are often neglected in policy documents and in the literature since most of the dietary intervention programs organized by government's community clinics are directed toward infants, young children, adolescents, and pregnant mothers [26]. Little is known about the malnutrition status of wetland community-dwelling older adults and how the physio-psychosocial and living circumstances place them at risk of malnutrition. This review and cross-sectional study will help to answer all these questions.

\section{Methods And Materials}

\section{Research design, Settings, sampling and participants}

We employed a cross-sectional research design, involving a socio-demographic survey and a formal questionnaire. Participants were recruited from ten wetland villages in the north-eastern region of Bangladesh through simple random sampling. Though, the age cut-off for elderly in South Asian countries is 60 years [27], we approached people aged 50 years and above considering physical fitness of the wetland community dwelling population in Bangladesh. The health condition or fitness of older adults live in wetland communities declines at early age and experiences the sign of ageing from 50 years [2830]. Additionally, several socio-demographic and economic characteristics like high illiteracy rate, lack of income/saving, stress and health unawareness are responsible for early ageing [31,32]. Under the given circumstances, we approached people aged $\geq 50$ years, where four hundred older adults aged 50 and above from the selected wetland villages agreed to participate in a person-centered general health 
assessment and a face-to-face interview. Study sample size was calculated through statistical sampling techniques and wetland villages were selected through random number generated by R-Programming language.

\section{Data collection}

Following the guidelines of Helsinki Declaration of 2000, the socio-demographic, economic, health and nutritional data were collected through a structure questionnaire including the Nestle Mini Nutrition Assessment questions, after taking written informed consent from each participant. Necessary medical equipment [Table 1] were used by a trained public health data enumerator to collect anthropometric data from the participants.

\section{Outcomes measures}

The Nestle Mini Nutrition Assessment - Short Form (MNA-SF) is a validated and widely used screening tool for identifying adults' malnourishment and malnutrition risk [33]. We used Nestlés (2009-revised version) MNA-SF that comprised six items: food intake, weight loss, mobility, psychological stress, neuropsychological problems and BMI [34]. The MNA-SF score lies among 0 to 14, which classified into three categories: well-nourished [12 $\leq$ MNA-SF score $<14]$, risk of malnutrition [ $8 \leq$ MNA-SF score $\leq 11]$ and malnourished [0 MNA-SFscore $\leq 7][33,34]$.

\section{Measurement of related health indicators}

The anthropometric measurement of older adult's height, weight, body mass index [BMI], blood pressure [BP] and random blood sugar [RBS] were measured using necessary medical equipment described in the Table 1.

\section{Data analysis}

We found no missing value in the dataset. Descriptive statistics were performed first and the MNA-SF short form technique was used to assess the malnutrition profile of wetland community-dwelling older adults. The association between older adult's malnutrition and physio-psychosocial factors were examined by using bivariate analysis. The Pearson Chi-square test was performed to determine the associated significant risk factors of malnutrition. The project's data management and statistical analyses were carried out through IBM SPSS Statistics 20.0. 


\section{Results}

\section{Demographic characteristics}

The mean age was 62.35 years, with a range of $50-90$ years. About 49.5 percent participants were young old (50-59 years) and rest of them were 60 years and older. Most participants (59.5 percent) were male and over half of the participants (59.8 percent) were illiterate. A large percentage (72 percent) were fishermen, farmers, or daily labors. The average monthly family income was 13,868 (\$163) Bangladeshi Taka where 33.3 percent elderly have income less than BDT 10,000 (USD 117) and a small portion (5.9 percent) elderly have income more than BDT 20,000 (USD 236). More than half of the respondents live in a nuclear family and 32.2 percent live in joint family where 10.9 percent were from extended family. It is observed that 25.3 percent elderly have single living arrangement followed by 70.9 percent are double arrangement and only 3.8 percent belongs to extended living arrangement (Table 2).

\section{Mini nutrition assessment of young and older adults lived in wetland community}

The nutritional status of the participants was assessed using Nestle short form Mini Nutritional Assessment-SF and presented in Figure 1. Analysis found that 59.75 percent participants live in wetland community were malnourished, following 39.75 percent were risk of malnutrition and a tiny 0.5 percent were normal nutrition (Figure 1.a.). Overall, the malnutrition status was higher in females than male and maximum 68.5 percent female respondents were malnourished, following 31.5 were at risk of malnutrition. On the other hand, 59.8 percent male respondents were malnourished and 45.4 percent were at risk of malnutrition (Figure 1.b.). Although, a small 0.08 percent male respondents were found wellnourished, no female respondents were found as normal nutritional status. Our study found an increase rate of malnutrition status with the increase of age of the wetland community-dwelling people aged 50 years and over. The rate of malnutrition was found higher among the older adult aged 70 and above. Older adults who were $60-69$ years old found 12.1 percent malnourish rate following 11.1 percent malnourish in the pre-elderly (50-59 years) age group (Figure 2.c.). Income was also found a significant factor of older adult's malnutrition. The pre-elderly and elderly whose income were less than BDT 10,000 (USD 117) or more than BDT 20,000 (USD 236) found more malnourished but, almost all the older adults live in this community were found at risk of malnutrition to malnourished (Figure 1.d.).

\section{Socio-demographic risk factors related to wetland community-dwelling older adults nutrition}

Respondent's socio-demographic risk factors of malnutrition were identified using Pearson's Chi-square test (Table 3 ). As the normal nutrition rate was very low [0.5 percent] in this dataset, we excluded these respondents from the dataset and assessed the respondents who were at risk of malnutrition and malnourished. From this table, respondent's age, gender, educational status, occupation, family type and 
income were found as the significant risk factors of malnutrition obtained by Chi-square association test (Table 3).

\section{Health factors related to wetland community-dwelling older adults' malnutrition}

About 140 (35.5 percent) older adults' self-rating health status were not good where 108 (77.1 percent) were malnourished and the rest 32 (22.9 percent) were at risk of malnutrition. The malnourished older adults in the wetland community were faced various comorbidities (e.g., diabetes, hypertension and sleeping disorders etc.). The prevalence of diabetes, hypertension and sleeping disorders in the study community were found $18.75,44.5$ and 56.5 percent respectively. The older adults' who were suffering from malnutrition were 21.4 percent diabetic, 53.56 percent hypertensive and 51.3 percent were facing severe sleeping disorders problems. On the other hand, the older adults' who were at risk of malnutrition were 15.1 percent diabetic, 56.7 percent hypertensive and 65.4 percent were suffering from sleeping disorders. The Pierson's Chi-square association test found self-rating health status, diabetes and sleeping disorder as the significant risk factors of malnutrition (Table 4).

\section{Discussion}

Our study was conducted among wetland community-dwelling people aged 50 years and above living in the North-east region of Bangladesh to understand the prevalence of malnutrition, malnutrition risks and the factors associated with malnutrition of wetland aging. This study has three limitations: firstly, this was a cross-sectional study that has lack strength in cause-effect analysis; secondly, the study was representative for the wetland communities in north-eastern part of Bangladesh; and finally, we did not assess dietary intake which may directly affect the nutritional status of older adults. However, it is the first study of its kind in wetland villages that generates several interesting findings; therefore, we compare and discuss the prevalence of malnutrition and risk factors of the wetland community-dwelling older adults with main-land people in Bangladesh and other South Asian countries in the following sections.

Most of the older adults were found in the pre-elderly age group (50-59 years) where the average age of the participants was sixty-two years. This aging pattern in wetland villages is similar to a study conducted among the older adults live in the main-land of the region by Rahman and the authors in 2021 [35]. Male older adults were higher than female in the wetland community and this result is comparable with the findings of some other community-based studies and the latest census report of Bangladesh $[25,35,36]$. The majority of the older adults were illiterate and involved in fishing, agricultural work, daily labor or no job sectors. The average monthly income was very low (BDT 13,863 or nearly \$163) and a majority number older adult's living arrangement was single. These findings are consistent with some other studies conducted in the North-eastern part of Bangladesh [25,35,37-39]. 
We found a higher prevalence of malnutrition and risk of malnutrition among the wetland communitydwelling older adults. In comparison to the other studies conducted among the older persons in other care settings of Bangladesh, Kabir and the authors reported 26 percent prevalence of malnutrition using MNASF as the measurement tool, following 40 and 53.8 percent malnutrition rate reported by Masum et al., [2015] and Hasan et al., (2020) respectively [40-42]. Comparing our results with the recent studies conducted on the overall community older adults in other South-Asian countries, the prevalence of malnutrition was reported as over 20 percent by India, Nepal, Sri Lanka and Pakistan respectively [4,4345]. Our study also showed prevalence of malnutrition to be higher among females, old-age and elderlies with low family income compared to their counterparts. This finding found consistent with the recent studies [41,45,46]. Although, no published studies were found that assessed Mini-nutritional status of the wetland community-dwelling older adults in South-Asian countries like Bangladesh. However, this comparison strongly suggests a higher prevalence of malnutrition among the wetland communitydwelling older adults.

Socio-demographic and economic profiles of elderly are the important influential factors for elderly malnutrition. Relating this, our study found age, education, gender, occupation, family type and income as the important influential socio-demographic and economic factors that were significantly associated with the wetland community-dwelling older adults' malnutrition. Some studies conducted on overall community older adults malnutrition status using Mini-nutritional assessment investigated age, gender, education, occupation and income as the potential socio-demographic and economic predictors of malnutrition $[44,45,47]$. It can be explained by the fact that the unemployed elderly possibly could have low financial status, resulting in low access to nutritional foods. Due to higher illiteracy and unemployment rate, the older persons economically depend on their caregivers and most of the caregivers in the wetland community are also unemployed and engaged in fishing and different agricultural work activities. It is interesting to note that older adults with low-income and those are in high-income group both presented high malnourishment. According to the existing literatures and our study, it is understandable that older population who have lack of access to income/saving and welfare schemes did not get sufficient nutrient-dense food and healthcare that increase the risk of malnutrition $[3,48,49]$. In this study, the older adults with high-income showed their poor nutritional knowledge about food choices and dietary intake that caused a nutritional vulnerability in this cohort. Consistent to our findings, study from India and Nepal had reported illiteracy and unemployment as the influential risk factors for older adult's malnutrition $[45,50]$.

Health factors are also responsible for the older adult's malnutrition. Elderly who are suffering from one or more comorbidities tends to be more prone to nutritional deficiencies [51,52]. Moreover, aging may come with an accumulation of diseases and impairments including cognitive and physical decline, 
depressive symptoms, emotional variations and poor oral health [35,53]. In our study, we found sleeping disorder, diabetes and poor health condition that were significantly associated with the nutritional status of wetland community-dwelling older adults which consistent with the existing literature. A study of Nepal, Tamang et al. (2019) reported that elderly sleeping disorder may bring the negative outcome like weakness and nutrition [45].

In conclusion, this is the first study on malnutrition conducted among community-dwelling older adults in the wetland area of Bangladesh, where internationally recognized instrument is used. The prevalence of malnutrition and risk of malnutrition found very high among the wetland community-dwelling older adults where respondent's age, gender, education, occupation and income are significantly associated with malnutrition. Elderly malnutrition also found higher with the advancement of age and female elderly are more vulnerable than male. The older persons who are suffering from sleeping disorder and selfrating health status is poor are suffering malnutrition problem more than their counterparts. According to the identified factors, the public health professionals should be encouraged by developing screening strategies to improve the nutritional status of the wetland community-dwelling older population in Bangladesh.

\section{Declarations}

\section{Ethical Approval}

This study was conducted under a project of University research Center (URC), Shahjalal University of Science and Technology (SUST), Bangladesh where the ethics approval was granted by the University Research Center, SUST under the project grant number PS/2018/1/10. Formal permission for data collection was sought from district civil surgeon office, Bangladesh.

\section{Funding}

University Research Centre (URC), SUST is a research institute organized by Shahjalal University of Science and Technology, Sylhet, Bangladesh. This project [Project Grant Number: PS/2018/1/10] was funded by the University Research Centre (URC), SUST. No funding was received to assist with the preparation of this manuscript.

\section{Author's contribution}

MMR, ZF and MH were contributed towards conception and design of the study. MMR and ZF were analyzed and interpreted the data. MMR, ZF, MZI, MTU and MH contributed in drafting of the article and 
revising it critically for important intellectual content and approving of the version to be published.

\section{Conflict of Interest}

The authors declared no conflict of interest.

\section{Acknowledgements}

Shahjalal University of Science and Technology (SUST), Bangladesh is a top leading research-based university in Bangladesh contributing in research through its core research sell "University Research Centre-SUST". We want to acknowledge SUST for approving this unique study for the well-being of wetland community-dwelling older adults. Again, we want to acknowledge the associated staffs who contributed towards the success of this study.

\section{References}

1. UN (2015). Transforming our world: The 2030 agenda for sustainable development. New York: United Nations, Department of Economic and Social Affairs.

2. WHO (2020). Malnutrition. World Health Organization. Retrieved from https://www.who.int/newsroom/q-a-detail/malnutrition.

3. WHO (2019). More than one in three low- and middle-income countries face both extremes of malnutrition. Retrieved from https://www.who.int/news/item/16-12-2019-more-than-one-in-three-low-and-middle-income-countries-face-both-extremes-of-malnutrition.

4. Joymati O, Ningombam M, Rajkumari B, Gangmei A. (2018). Assessment of nutritional status among elderly population in a rural area in Manipur: community-based cross-sectional study. Int $\mathrm{J}$ Community Med Public Heal., 5(7), 3125-3129.

5. Kohlmeier M, Nowson CA, DiMaria-Ghalili RA, Ray S. (2015). Nutrition Education for the Health Care Professions. J Biomed Educ., 2015, 380917.

6. Vafaei Z, Mokhtari H, Sadooghi Z, Meamar R, Chitsaz A, Moeini M. (2013). Malnutrition is associated with depression in rural elderly population. J Res Med Sci., 18(1), S15-S19.

7. Spencer PS, Palmer VS. (2012). Interrelationships of undernutrition and neurotoxicity: food for thought and research attention. Neurotoxicology, 33(3), 605-616.

8. Chan RSM, Woo J. (2010). Prevention of overweight and obesity: how effective is the current public health approach. Int J Environ Res Public Health, 7(3), 765-783.

9. Byomkesh T, Nakagoshi N, Md. Shahedur R. (2008). State and management of wetlands in Bangladesh. Landsc Ecol Eng., 5(1), 81. 
10. BWDB (2007). Perennial and main wetlands of Bangladesh. Ministry of Water Resources, Bangladesh.

11. Chaudhury M. (2008) A Situation analysis of ecosystem services and poverty linkages in Bangladesh. BRAC.

12. Shahed SS, Rahman MM, Misha FA (2016). Building Resilience in the Char Area: baseling findings of the char development settlement project (phase IV), BRAC Research and Evaluation Division.

13. Hamiduzzaman M, de Bellis A, Abigail W, Kalaitzidis E. (2018). Elderly Women in Rural Bangladesh: Healthcare Access and Ageing Trends. South Asia Res, 38(2), 113-129. https://doi.org/10.1177/0262728018767018

14. United Nations (2015). World Population Ageing 2015. Department of Economic and Social Affairs, Population Division.

15. BBS (2015). Elderly Population in Bangladesh: Current Features and Future Perspectives. Ministry of Planning.

16. Müller O, Krawinkel M. (2005). Malnutrition and health in developing countries. CMAJ., 173(3), 279286.

17. FAO (2008). Scoping agriculture - wetland interactions: Towards a sustainable multiple-response strategy, United Nations. Retraived May 25, 2021, from http://www.fao.org/3/i0314e/i0314e00.htm.

18. Yousuf Haroon AK, Kibria G. (2007). Wetlands: Biodiversity and Livelihood Values and Significance with Special Context to Bangladesh. In: Wetland Science Springer, New Delhi.

19. Akter R, Thilsted SH, Hossain N, Ishihara H, Yagi N. (2019). Fish is the Preferred Animal-Source Food in the Rural Community of Southern Bangladesh. Sustainability, 11(20), 5764.

20. Horwitz P, Finlayson CM. (2011). Wetlands as Settings for Human Health: Incorporating Ecosystem Services and Health Impact Assessment into Water Resource Management. Bioscience, 61(9), 678688. https://doi.org/10.1525/bio.2011.61.9.6.

21. BRAC (2018). Malnutrition higher in coastal and haor areas, households have $16 \%$ less income. Retraived May 25, 2021, from https://www.brac.net/latest-news/item/1161-malnutrition-higher-incoastal-and-haor-areas-households-have-16-less-income.

22. Alam MB. (2018). Inequalities in access to primary education: an investigation on "haor" (wetland) areas in Bangladesh. World Voices Nexus. Retraived May 25, 2021, from https://www.worldcces.org/article-1-by-alam/inequalities-in-access-to-primary-education-aninvestigation-on-haor-wetland-areas-in-bangladesh.

23. Das S, Mia MN, Hanifi SMA, Hoque S, Bhuiya A. (2017). Health literacy in a community with low levels of education: findings from Chakaria, a rural area of Bangladesh. BMC Public Health, 17(1), 203.

24. Agarwalla R, Saikia AM, Baruah R. (2015). Assessment of the nutritional status of the elderly and its correlates. J Family Community Med., 22(1), 39-43. 
25. Rahman M, Begum M, Uddin M, Rahman M. (2018). Factors Affecting Health Status of Urban Aged Population: Evidence from Sylhet, Bangladesh. Indian J Gerontol., 32(1),103-118.

26. Ministry of Health and Family Welfare B. (2016). Bangladesh Essential Health Service Package (ESP). Retraived May 25, 2021, from https://www.hfgproject.org/essential-package-of-healthservices-country-snapshot-bangladesh/.

27. UNFPA (2009). Demographic Prognosis for South Asia: A future of rapid ageing. United Nations Population Fund. Retraived May 25, 2021, from https://ifa.ngo/publication/demographics/demographics-prognosis-for-south-asia-a-future-of-rapidaging/.

28. Platinum Dermatology (2016). The seven signs of ageing - Platinum Dermatology. Retraived May 25, 2021, from https://platinumdermatology.com.au/articles/the-seven-signs-of-ageing/.

29. Bishwajit G, Tang S, Yaya S, Feng Z. (2017). Participation in physical activity and back pain among an elderly population in South Asia. J Pain Res., 10, 905-913.

30. Clarke LH, Korotchenko A. (2014). Aging and the Body: A Review. Can J Aging., 30(3), 495-510.

31. Galiana L, Gutiérrez M, Sancho P, Francisco E-H, Tomás JM. (2016). Socio-Demographic Variables and Successful Aging of the Angolan Elderly. Scientifica (Cairo)., 2016, 5306756.

32. Dartigues JF, Helmer C, Letenneur L. (1999). Socio-Demographic Risk Factors for Dementia and Alzheimer's Disease in the Paquid Study. Epidemiology of Alzheimer's Disease: From Gene to Prevention. Research and Perspectives in Alzheimer's Disease. In: Springer, Berlin, Heidelberg.

33. Huhmann MB, Perez V, Alexander DD, Thomas DR. (2009). A self-completed nutrition screening tool for community-dwelling older adults with high reliability: A comparison study. J Nutr Health Aging, 17(4), 339-344. https://doi.org/10.1007/s12603-013-0015-x.

34. Nestle Nutrition Institute (2009). Mini Nutritional Assessment MNA. Retraived May 25, 2021, from https://www.mna-elderly.com/forms/mini/mna_mini_english.pdf.

35. Rahman M, Hamiduzzaman M, Akter M, Farhana Z, Hossain M, Hasan M, et al. (2021). Frailty indexed classification of Bangladeshi older adults' physio-psychosocial health and associated risk factors- a cross-sectional survey study. BMC Geriatr., 21(1),3. https://doi.org/10.1186/s12877-02001970-5.

36. BBS (2011). Population and Housing Census, 2011. National Report-Volume - 4. Bangladesh Bureau of Statistics.

37. Datta PB, Islam N, Paul GK. (2018). Factors responsible for the health status of elderly people: A case study in Sylhet district. Int J Med Heal Res., 4(4), 72-77.

38. Khan N, Mondal NI, Hoque N, Islam MS. (2014). A study on quality of life of elderly population in Bangladesh., 2(4), 152-157.

39. Uddin MT, Islam MN, Alam MJ, Bahar GU. (2010). Socio-Economic status of Elderly of Bangladesh: A Statistical Analysis. Journal of Applied Sciences, 10(23), 3060-3067. 
40. Hossain ZM, Pal A, Hasan AM, Parvej SM, Nahar N, Abdullah-Al-Asif. (2016). Nutritional status and socio-demographic characteristics of the people of south- west coastal region in Bangladesh. Asian Australas J Biosci Biotechnol., 1(2), 323-332.

41. Kabir ZN, Ferdous T, Cederholm T, Khanam MA, Streatfied K, Wahlin Å. (2006). Mini Nutritional Assessment of rural elderly people in Bangladesh: the impact of demographic, socio-economic and health factors. Public Health Nutr., 9(8), 968-974.

42. Masum $M$, Haqe $M$, Haque $M$, Saha $P$, Naser M, Mondal S, et al. (2015). Nutritional Status of an Aged Population in Selected Rural Area of Bangladesh. EC Nutr., 2(1), 278-282.

43. Kaleem S, Parveen SA, Mashori A, Bilal A, Aleem K, Tazeen A, et al. (2014). Malnutrition and its Risk Factors Particularly Family System in Elderly Population of Karachi. J Med Heal Sci., 8(1), 72-75.

44. Rathnayake KM, Wimalathunga M, Weech M, Jackson KG, Lovegrove JA. (2015). High prevalence of undernutrition and low dietary diversity in institutionalised elderly living in Sri Lanka. Public Health Nutr., 18(15), 2874-8280.

45. Tamang MK, Yadav UN, Hosseinzadeh H, Kafle B, Paudel G, Khatiwada S, et al. (2019). Nutritional assessment and factors associated with malnutrition among the elderly population of Nepal: a cross-sectional study. BMC Res Notes., 12(1), 246.

46. Damayanthi HDWT, Moy FM, Abdullah KL, Dharmaratne SD. (2018). Prevalence of malnutrition and associated factors among community-dwelling older persons in Sri Lanka: a cross-sectional study. BMC Geriatr., 18(1), 199.

47. Kabir ZN, Ferdous T, Cederholm T, Khanam MA, Streatfied K, Wahlin Å. (2016). Mini Nutritional Assessment of rural elderly people in Bangladesh: the impact of demographic, socio-economic and health factors - ERRATUM. Public Health Nutr., 19(12), 2290.

48. Akhtar S. (2016). Malnutrition in South Asia-A Critical Reappraisal. Crit Rev Food Sci Nutr., 56(14), 2320-2330.

49. Nugent R, Levin C, Hale J, Hutchinson B. (2020). Economic effects of the double burden of malnutrition. Lancet, 395(10218), 156-164.

50. Konda S, B. P. RK, Giri PA. (2018). Prevalence of malnutrition and its determinants in an elderly people in South India. Int J Community Med Public Heal., 5(8), 3570-3576. https://dx.doi.org/10.18203/2394-6040.ijcmph20183100.

51. Wells JL, Dumbrell AC. (2006). Nutrition and aging: assessment and treatment of compromised nutritional status in frail elderly patients. Clin Interv Aging., 1(1), 67-79.

52. Agarwal E, Miller M, Yaxley A, Isenring E. (2013). Malnutrition in the elderly: A narrative review. Maturitas, 76(4), 296-302.

53. Fávaro-Moreira NC, Krausch-Hofmann S, Matthys C, Vereecken C, Vanhauwaert E, Declercq A, et al. (2016). Risk Factors for Malnutrition in Older Adults: A Systematic Review of the Literature Based on Longitudinal Data. Adv Nutr., 7(3), 507-22.

\section{Tables}


Table 1. Measurements of Height, Weight, BMI, BP and RBS

\begin{tabular}{|c|c|c|}
\hline $\begin{array}{l}\text { Health } \\
\text { Indicators }\end{array}$ & Instruments & Measurement procedures \\
\hline Height (m) & Height measuring scale (Stadiometer) & $\begin{array}{l}\text { - Stand without shoes and simple summer clothes } \\
\text { - Look straight ahead and keep shoulders to level }\end{array}$ \\
\hline Weight (Kg) & Weight measuring scale (Seca Digital) & $\begin{array}{l}\text {-Keeping normal Summer clothes } \\
\text { - Keeping the respondents simple as far as possible } \\
\text { during the measurement }\end{array}$ \\
\hline $\begin{array}{l}\mathrm{BMI} \\
\left(\mathrm{Kg} / \mathrm{m}^{2}\right)\end{array}$ & Computer & \\
\hline BP (mmHg.) & $\begin{array}{l}\text { Electronic BP Monitor (OMB) } \\
\text { Model: BP-1307 }\end{array}$ & $\begin{array}{l}\text { - Well seated } \\
\text { - After } 5 \text { minutes rest } \\
\text { - Average of three consecutive readings }\end{array}$ \\
\hline $\begin{array}{l}\text { RBS } \\
(\mathrm{mmol} / \mathrm{L})\end{array}$ & $\begin{array}{l}\text { Digital RBS Machine (Vivacheck }{ }^{\mathrm{TM}} \text { Ino.), } \\
\text { Model: VGM01 }\end{array}$ & $\begin{array}{l}\text { - Time between breakfast and lunch } \\
\text { - Time between lunch and dinner }\end{array}$ \\
\hline
\end{tabular}

Table 2: Socio economic and demographic characteristics of the elderly.

\begin{tabular}{|c|c|c|c|}
\hline Characteristics & & Frequency & Percentage \\
\hline \multirow[t]{5}{*}{ Age } & $50-59$ & 198 & 49.5 \\
\hline & $60-69$ & 143 & 35.8 \\
\hline & $70-79$ & 41 & 10.3 \\
\hline & $80-89$ & 16 & 4.0 \\
\hline & $90-99$ & 2 & 5.0 \\
\hline \multirow[t]{2}{*}{ Gender } & Female & 162 & 40.5 \\
\hline & Male & 238 & 59.5 \\
\hline \multirow[t]{3}{*}{ Education } & Illiterate & 238 & 59.8 \\
\hline & Primary & 122 & 30.7 \\
\hline & Above Primary & 38 & 9.5 \\
\hline \multirow[t]{2}{*}{ Occupation } & Public/Private Jobs & 109 & 27.5 \\
\hline & $\begin{array}{c}\text { Fishing/Agriculture/Other } \\
\text { Works }\end{array}$ & 228 & 72.5 \\
\hline \multirow[t]{3}{*}{ Family Type } & Nuclear & 227 & 56.7 \\
\hline & Joint & 129 & 32.2 \\
\hline & Extended & 43 & 10.7 \\
\hline \multirow{3}{*}{$\begin{array}{l}\text { Monthly Income in Taka (Dollars, considering } \$ 1=84.79 \\
\text { BDT, Accessed: November } 06,2020 \text { ) }\end{array}$} & $<10000(<\$ 117)$ & 126 & 33.3 \\
\hline & $\begin{array}{c}10000 \text { to } 19999 \text { (\$118 to } \\
\$ 235 \text { ) }\end{array}$ & 195 & 51.2 \\
\hline & $>20000(>\$ 236)$ & 59 & 5.9 \\
\hline \multirow[t]{3}{*}{ Living arrangement } & Single & 101 & 25.3 \\
\hline & Double & 283 & 70.9 \\
\hline & Extended & 15 & 3.8 \\
\hline
\end{tabular}


Table 3. Socio-demographic factors related to wetland community-dwelling older adults nutrition.

\begin{tabular}{|c|c|c|c|c|c|c|}
\hline \multirow[t]{2}{*}{ Characteristics } & & \multicolumn{2}{|c|}{ Malnutrition } & \multicolumn{2}{|c|}{$\begin{array}{l}\text { At risk of } \\
\text { Malnutrition }\end{array}$} & \multirow[t]{2}{*}{$\begin{array}{l}\text { P- } \\
\text { Value }\end{array}$} \\
\hline & & $\mathrm{N}$ & $\%$ & $\mathrm{~N}$ & $\%$ & \\
\hline \multirow[t]{3}{*}{ Education } & Illiterate & 167 & 70.2 & 71 & 29.8 & \multirow{3}{*}{0.0001} \\
\hline & Primary & 48 & 40.0 & 72 & 60.0 & \\
\hline & Above Primary & 23 & 60.5 & 15 & 39.5 & \\
\hline \multirow[t]{2}{*}{ Gender } & Female & 111 & 68.5 & 51 & 31.1 & \multirow[t]{2}{*}{0.0001} \\
\hline & Male & 128 & 45.8 & 108 & 54.2 & \\
\hline \multirow[t]{2}{*}{ Occupation } & Public/Private Jobs & 44 & 41.1 & 63 & 58.9 & \multirow[t]{2}{*}{0.0001} \\
\hline & $\begin{array}{l}\text { Fishing/Agriculture/Other } \\
\text { Works }\end{array}$ & 193 & 67 & 95 & 33.0 & \\
\hline \multirow[t]{3}{*}{ Family Type } & Nuclear & 126 & 55.8 & 100 & 44.2 & \multirow[t]{3}{*}{0.001} \\
\hline & Joint & 76 & 58.9 & 53 & 41.1 & \\
\hline & Extended & 37 & 86 & 6 & 14.0 & \\
\hline \multirow[t]{3}{*}{ Age } & $50-59$ & 83 & 76.9 & 25 & 23.1 & \multirow[t]{3}{*}{0.067} \\
\hline & $60-69$ & 55 & 64.70 & 30 & 45.3 & \\
\hline & $70+$ & 24 & 44.2 & 19 & 55.8 & \\
\hline \multirow{3}{*}{$\begin{array}{l}\text { Monthly Income in Taka (Dollars, considering } \\
\$ 1=84.79 \text { BDT, Accessed: November } 06,2020 \text { ) }\end{array}$} & $<10000(<\$ 117)$ & 85 & 67.5 & 41 & 32.5 & \multirow[t]{3}{*}{0.001} \\
\hline & $\begin{array}{l}10000 \text { to } 19999 \text { (\$118 to } \\
\$ 235 \text { ) }\end{array}$ & 95 & 49.0 & 99 & 51.0 & \\
\hline & $>20000(>\$ 236)$ & 41 & 69.5 & 18 & 30.5 & \\
\hline
\end{tabular}

Table 4. Health factors related to wetland community-dwelling older adults nutrition.

\begin{tabular}{|c|c|c|c|c|c|c|}
\hline \multirow{3}{*}{ Characteristics } & & \multicolumn{4}{|c|}{ Screening nutrition status } & \multirow{3}{*}{ P-Value } \\
\hline & & \multicolumn{2}{|c|}{ Malnutrition } & \multicolumn{2}{|c|}{ Risk of malnutrition } & \\
\hline & & $\mathrm{N}$ & $\%$ & $\mathrm{~N}$ & $\%$ & \\
\hline \multirow[t]{2}{*}{ Health Status } & Good & 131 & 50.8 & 127 & 49.2 & \multirow{4}{*}{$\begin{array}{l}0.000 \\
0.073\end{array}$} \\
\hline & Not-good & 108 & 77.1 & 32 & 22.9 & \\
\hline \multirow[t]{2}{*}{ Diabetes } & Yes & 51 & 68.0 & 24 & 32.0 & \\
\hline & No & 187 & 58.1 & 135 & 41.9 & \\
\hline \multirow[t]{3}{*}{ Blood Pressure } & High & 36 & 53.7 & 31 & 46.3 & \multirow[t]{3}{*}{0.507} \\
\hline & Low & 92 & 60.9 & 59 & 39.1 & \\
\hline & Normal & 111 & 61.7 & 69 & 38.3 & \\
\hline \multirow{2}{*}{$\begin{array}{l}\text { Sleeping } \\
\text { Disorder }\end{array}$} & Yes & 122 & 53.2 & 104 & 46.8 & \multirow[t]{2}{*}{0.004} \\
\hline & No & 116 & 66.0 & 55 & 34.0 & \\
\hline
\end{tabular}

\section{Figures}


a.

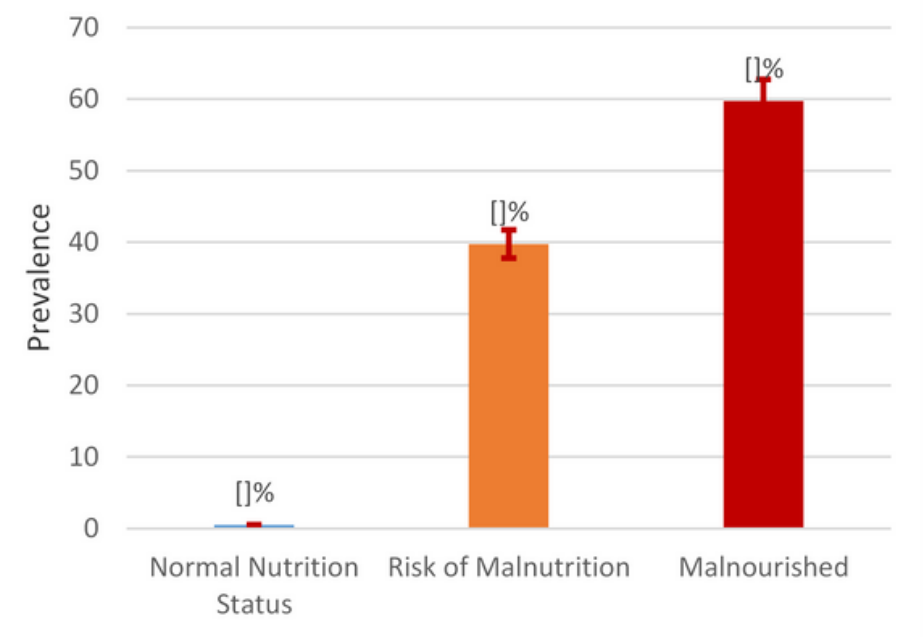

c.

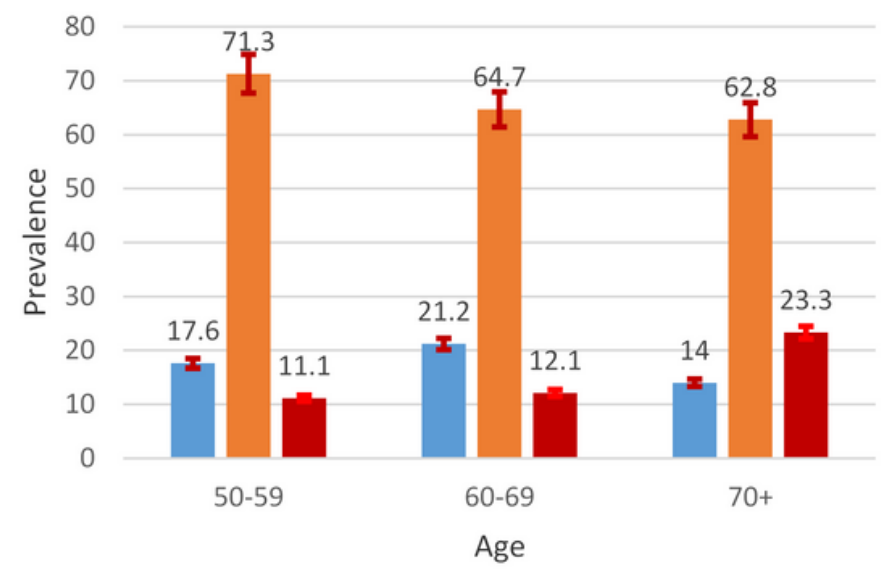

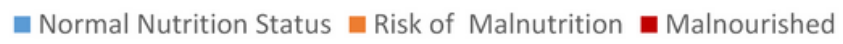

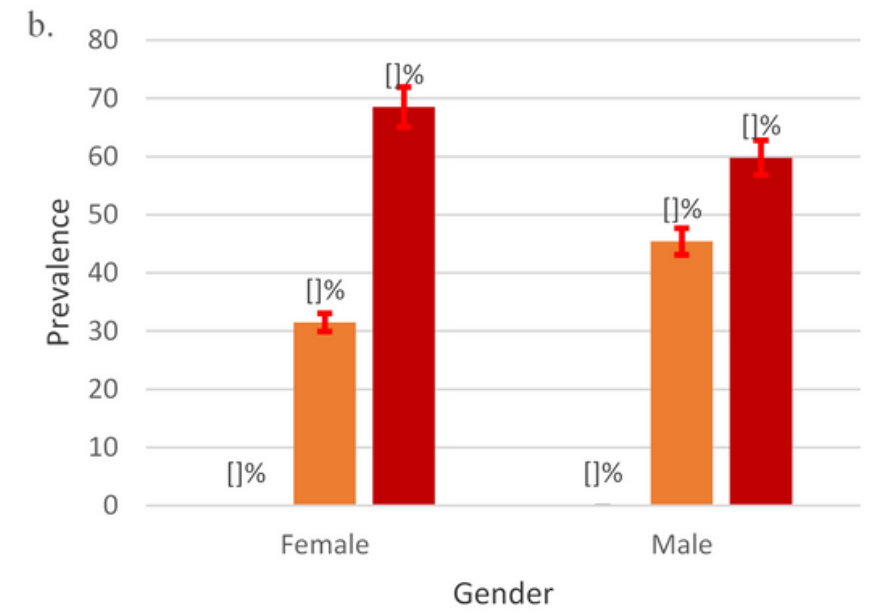

n Normal Nutrition Status a Risk of Malnutrition malnourished

d.

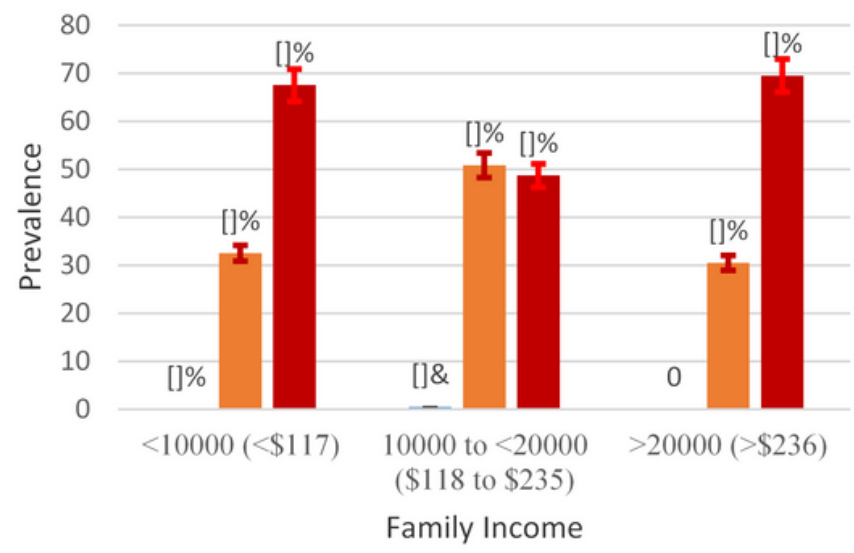

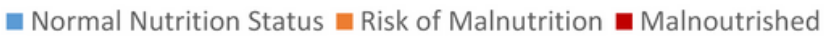

\section{Figure 1}

Mini nutritional status of respondents lived in wetland community: (a.) Overall Nutritional Status; (b.) Mini-Nutritional Status by Gender; (c.) Mini-Nutritional Status by Age and (d.) Mini-Nutritional Status by Family Income. 